\title{
PELATIHAN DALAM RANGKA PENGEMBANGAN KEPROFESIAN BERKELANJUTAN GURU: SUATU TINJAUAN LITERATUR
}

\author{
Yustinus Windrawanto \\ windrawanto@staff.uksw.edu \\ Program Studi Bimbingan dan Konseling \\ FKIP - Universitas Kristen Satya Wacana
}

\begin{abstract}
ABSTRAK
Pengembangan keprofesian berkelanjutan bagi guru merupakan kebijakan pemerintah dalam rangka peningkatan mutu pendidikan, melalui peningkatn mutu guru. Salah satu kegiatan dalam pengembangan keprofesian berkelanjutan adalah pelatihan guru. Pelatihan guru perlu dirancang agar memberikan dampak yang nyata. Artikel ini disusun dengan metode tinjauan literatur. Terdapat berbagai model pelatihan guru dalam rangka pengembangan keprofesian berkelanjutan (Luneta, 2012). Dengan mempertimbangkan langkah dasar pelatihan menurut Furjanic dan Trotman (2000) dan tinjauan dari berbagi teori, maka disimpulkan bahwa model pelatihan yang sesuai adalah model Schoolfocused: University school Partnerships (Berfokus sekolah : kemitraan sekolah dan perguruan tinggi).
\end{abstract}

Kata kunci: Pengembangan Keprofesian Berkelanjutan, pelatihan guru

\section{PENDAHULUAN}

Kualitas pendidikan tentunya dipengaruhi oleh beberapa faktor. Salah satu faktor yang dipercaya mempengaruhi kualitas pendidikan adalah faktor kualitas guru. Bahkan secara tegas McKinsey \& Co (2007) menyatakan bahwa kualitas sistem pendidikan tidak dapat mengalahkan kualitas guru dalam mempengaruhi kualitas pendidikan. Dengan kata lain dapat dinyatakan bahwa sebaik apapun sistem pendidikan yang dibangun, namun jika tidak diikuti dengan kualitas guru yang baik, maka kualitas pendidikan tidak dapat diharapkan meningkat. Dari pendapat tersebut dapat dipahami bahwa peningkatan kualitas guru harus mendapatkan perhatian utama.

Terdapat beberapa cara yang dapat digunakan untuk mendapatkan guru yang memiliki kualitas kompetensi yang baik, misalnya dapat dimulai dari sistem perekrutan calon mahasiswa LPTK atau melakukan pembinaan bagi guru yang telah menjadi bagian dari suatu sistem di satuan pendidikan. Salah satu bentuk pembinaan atau peningkatan kompetensi yang dapat dilakukan adalah dengan pelatihan guru. Saat ini banyak pihak melakukan pelatihan bagi guru. Persoalannya adalah pelatihan yang seperti apa yang mampu menjamin peningkatan kompetensi guru?

\section{KOMPETENSI GURU}

Kompetensi guru di Indonesia telah diatur dalam Peraturan Menteri Pendidikan dan Kebudayaan nomer 16 tahun 2007 tentang Standar Akademik dan Kompetensi Guru. Di dalam Peraturan Menteri tersebut dinyatakan bahwa standar kompetensi guru 
dikembangkan secara utuh dari empat kompetensi utama, yaitu kompetensi pedagogik, kepribadian, sosial, dan profesional. Keempat kompetensi tersebut terintegrasi dalam kinerja guru. Di dalam artikel ini, yang akan digunakan dalam pembahasan adalah kompetensi pedagogik dan profesional yang diukur melalui uji kompetensi guru.

Kompetensi pedagogik guru yang diatur dalam peraturan menteri tersebut adalah sebagai berikut menguasai karakteristik peserta didik dari aspek fisik, moral, sosial, kultural, emosional, dan intelektual; menguasai teori belajar dan prinsip-prinsip pembelajaran yang mendidik; mengembangkan kurikulum yang terkait dengan mata pelajaran/bidang pengembangan yang diampu; menyelenggarakan pembelajaran yang mendidik; memanfaatkan teknologi informasi dan komunikasi untuk kepentingan pembelajaran; memfasilitasi pengembangan potensi peserta didik untuk mengaktualisasikan berbagai potensi yang dimiliki; berkomunikasi secara efektif, empatik, dan santun dengan peserta didik; menyelenggarakan penilaian dan evaluasi proses dan hasil belajar; memanfaatkan hasil penilaian dan evaluasi untuk kepentingan pembelajaran; melakukan tindakan reflektif untuk peningkatan kualitas pembelajaran. Kompetensi yang telah dinyatakan di atas merupakan kompetensi inti. Kompetensi tersebut masih dapat dijabarkan ke dalam kompetensi-kompetensi yang lebih rinci.

Kompetensi profesional guru yang diatur dalam peraturan menteri tersebut adalah menguasai materi, struktur, konsep, dan pola pikir keilmuan yang mendukung mata pelajaran yang diampu; menguasai standar kompetensi dan kompetensi dasar mata pelajaran/bidang pengembangan yang diampu; mengembangkan materi pembelajaran yang diampu secara kreatif; mengembang- kan keprofesionalan secara berkelanjutan dengan melakukan tindakan reflektif; memanfaatkan teknologi informasi dan komunikasi untuk berkomunikasi dan mengembangkan diri. Sebagaimana kompetensi pedagogik, kompetensi profesional yang telah dinyatakan di atas, merupakan kompetensi inti. Kompetensi profesional tersebut masih dapat dijabarkan ke dalam kompetensikompetensi yang lebih rinci.

\section{PENGEMBANGAN KEPROFESIAN BERKELANJUTAN}

Salah satu kompetensi profesional guru sebagaimana diatur dalam Peraturan Menteri Pendidikan dan Kebudayaan nomer 16 tahun 2007 adalah mengembangkan keprofesionalan secara berkelanjutan dengan melakukan tindakan reflektif. Pengembangan keprofesian berkelanjutan adalah bentuk pembelajaran berkelanjutan bagi guru yang merupakan kendaraan utama dalam upaya membawa perubahan yang diinginkan berkaitan dengan keberhasilan siswa (Kemdiknas, 2011). Lebih lanjut diuraikan bahwa untuk konteks Indonesia, pengembangan keprofesian berkelanjutan memiliki kekhususan sebagai berikut (Kemdiknas, 2011). Dalam konteks Indonesia, $\mathrm{PKB}$ adalah pengembangan keprofesian berkelanjutan yang dilaksanakan sesuai dengan kebutuhan guru untuk mencapai standar kompetensi profesi dan/atau meningkatkan kompetensinya di atas standar kompetensi profesinya yang sekaligus berimplikasi kepada perolehan angka kredit untuk kenaikan pangkat/jabatan fungsional guru.

Day (dalam Rose \& Reynolds, 2007) menyusun suatu definisi pengembangan keprofesian guru sebagai berikut :

Professional development consists of all natural learning experiences and those conscious and planned activities which are intended to be of direct or indirect benefit to the individual, group or school, which contribute, through these, to 
the quality of education in the classroom. It is the process by which, alone and with others, teachers review, renew and extend their commitment as change agents to the moral purpose of teaching; and by which they acquire and develop critically the knowledge, skills and emotional intelligence essential to good professional thinking, planning and practice with children, young people and colleagues throughout each phase of their teaching lives.

Inti dari pendapat Day adalah bahwa pengembangan profesional meliputi semua pengalaman belajar yang dimaksudkan untuk memberikan manfaat kepada individu guru, kelompok atau sekolah, yang berkontribusi meningkatkan kualitas pendidikan. Melalui proses ini guru dapat memperbaharui dan mengembangkan komitmen mereka sebagai agen perubahan untuk pengembangan moral, kekritisan, ketrampilan, kecerdasan emosional, yang meningkatkan profesionalitas mereka dalam melayani rekan kerja dan siswa para guru. Pendapat Day di atas didukung oleh pernyataan Greene (dalam Moeini, 2008) yang menyatakan bahwa guru diharapkan menjadi agen reformasi pendidikan, guru perlu diberdayakan untuk memikirkan apa yang guru lakukan dan merasakan ada alternatif yang berbeda. Guru perlu memiliki sudut pandang yang lebih luas tentang masalah-masalah pendidikan yang perlu ditransformasi dan dikembangkan. Cheung and Cheng (dalam Moeini, 2008) juga menyatakan bahwa guru seharusnya sadar pentingnya pengembangan diri secara lebih strategis dengan tujuan pencapaian tujuan individu guru dan misi sekolah dan dapat diformulasikan dengan perencanaan pengembangan keprofesiannya.

Kegiatan pengembangan keprofesian berkelanjutan guru dapat dilakukan dalam tiga bentuk, yaitu pengembangan diri (meliputi diklat fungsional dan kegiatan kolektif guru), publikasi ilmiah, dan pengembangan karya inovatif. Pengembangan keprofesian berkelanjutan sebagai kebijakan dari pemerintah dalam rangka peningkatan kualitas pendidikan, khususnya pada area manajemen pendidik dan tenaga kependidikan. Herawan dan Hartini (2014) menyatakan bahwa manajemen tenaga pendidik dan tenaga kependidikan merupakan aktivitas yang harus dilakukan mulai dari tenaga pendidikan dan kependidikan itu masuk ke dalam organisasi pendidikan sampai akhirnya berhenti melalui proses perencanaan SDM, perekrutan, seleksi, penempatan, pemberian kompensasi, penghargaan, pendidikan, dan latihan/ pengembangan dan pemberhentian.

Dari definisi yang dirumuskan oleh Herawan dan Hartini (2014) di atas, nampak jelas bahwa pengembangan diri yang berupa diklat fungsional merupakan bagian dari manajemen pendidik dan tenaga kependidikan. Dalam artikel ini, pembahasan akan dibatasi pada kegiatan pengembangan diri, lebih khusus lagi pada pelaksanan pelatihan.

Kennedy (dalam Rose \& Reynolds, 2007) mengidentifikasikan sembilan model pengembangan keprofesian berkelanjutan yaitu training (diberikan oleh ahli dan berfokus pada ketrampilan), award bearing (berkaitan dengan pemberian beasiswa pendidikan lanjut), defecit (berkaitan dengan pelayanan terhadap mengatasi kekurangan yang ada pada masing-masing individu guru), cascade (dapat disajikan dengan sumber daya yang murah, kurang melibatkan unsur kolaboratif dalam pelaksanaannya), standards based (mengandaikan bahwa standar pendidikan telah disusun secara efektif dan baku), coaching/mentoring (relasi dapat dikembangkan secara konstruktif, memerlukan fasilitator yang dapat berkomunikasi dengan baik), community of practice (kelompok dengan dasar pengetahuan yang sama dapat bekerja sama, ada potensi masalah yang 
tidak terselesaikan dan tidak berkembang karena anggotanya memiliki tingkat kemampuan yang sama), action research (memungkinkan guru untuk mencoba metode yang berbeda khususnya jika dilakukan secara kolaboratif), transformative (dapat merupakan kombinasi dari beberapa model lain dengan memperhatikan masalah-masalah yang sedang dibicarakan).

Luneta (2012) menyajikan pula model pengembangan keprofesian berkelanjutan sebagai suatu ringkasan dari berbagai penelitian (misalnya penelitian Steiner, Johnson et al, dan Blazer). Model yang dikemukakan oleh Luneta dapat dilihat pada tabel di bawah ini. berbasis pebelajar (designing learner-based training), penyajian pelatihan yang menjamin pembelajaran (delivering training that ensure learning), dan evaluasi proses pelatihan (evaluating the training process).

\section{ANALISIS KEBUTUHAN PELATIHAN}

Kebutuhan pelatihan dapat diperoleh dengan menganalisa kesenjangan antara tujuan yang akan dicapai dan kondisi saat ini. Dari analisis ini dapat diketahui potensi masalah yang dapat menghambat ketercapaian tujuan. Dalam pengembangan keprofesian berkelanjutan guru, tujuan akhirnya

\begin{tabular}{|c|c|c|}
\hline Model & Metode Penyajian & Tujuan \\
\hline Off-site programmes & $\begin{array}{l}\text { Di universitas berbasis kuliah, lokakarya guru, } \\
\text { seminar, model pengembangan ketrampilan, } \\
\text { dan model berbasis proyek. }\end{array}$ & $\begin{array}{l}\text { Sesuai untuk peningkatan } \\
\text { kualifikasi guru dan pengetahuan }\end{array}$ \\
\hline $\begin{array}{l}\text { School based } \\
\text { (Berbasis sekolah) }\end{array}$ & $\begin{array}{l}\text { Observasi kelas, program mentoring, lokakarya } \\
\text { guru, seminar, penelitian tindakan, studi kasus, } \\
\text { model pengembangan ketrampilan, model } \\
\text { berbasis proyek, coaching }\end{array}$ & $\begin{array}{l}\text { Paling efektif untuk peningkatan } \\
\text { strategi pembelajaran. }\end{array}$ \\
\hline $\begin{array}{l}\text { School focused: } \\
\text { University school } \\
\text { Partnerships (Berfokus } \\
\text { sekolah : kemitraan } \\
\text { sekolah dan perguruan } \\
\text { tinggi) }\end{array}$ & $\begin{array}{l}\text { Lokakarya sekolah, penelitian tindakan, diskusi } \\
\text { kelompok, observasi pembelajaran dari praktek } \\
\text { yang baik, model berbasis proyek, model } \\
\text { pengembangan ketrampilan, coaching, } \\
\text { mentoring, dan lesson study }\end{array}$ & $\begin{array}{l}\text { Penyegaran dan peningkatan } \\
\text { pengetahuan konten dan } \\
\text { ketrampilan pengajaran berbasis } \\
\text { pengetahuan guru. }\end{array}$ \\
\hline $\begin{array}{l}\text { Distance Education } \\
\text { (Pendidikan jarak jauh) }\end{array}$ & Kuliah jarak jauh, ACE, PGCE & $\begin{array}{l}\text { Sesuai untuk meningkatkan } \\
\text { kualifikasi guru dan pengetahuan } \\
\text { konten. }\end{array}$ \\
\hline
\end{tabular}

Dalam pedoman yang dikeluarkan oleh pemerintah Kemdinas, 2011), kegiatan pelatihan harus mengutamakan kebutuhan guru untuk pencapaian standar dan/atau peningkatan kompetensi profesi khususnya berkaitan dengan melaksanakan layanan pembelajaran. Untuk itulah dibutuhkan suatu manajemen pelatihan yang terjamin kualitas hasilnya, bukan hanya sekedar pemenuhan aturan yang ditandai dengan diperolehnya sertifikat atau surat tanda lulus pelatihan. Artikel ditulis mengikuti langkah dasar proses pelatihan yang dikemukakan oleh Furjanic dan Trotman (2000), yaitu analisis kebutuhan pelatihan (assessing the need for training), perancangan pelatihan adalah guru yang efektif (Luneta, 2012). Dari berbagai penelitian, Luneta (2012) mengidentifikasi beberapa alasan pengembangan keprofesian guru dengan peran utama mengarahkan pada guru yang efektif. Alasan yang diajukan oleh Luneta (2012) adalah sebagai berikut:

1. Untuk memperbaiki ketrampilan unjuk kerja individu guru atau kelompok tenaga kependidikan melalui pendekatan yang konstruktivistik. Guru dituntut dan diperlakukan sebagai pembelajar aktif, yang dilibatkan dalam tugas-tugas konkret yaitu pengajaran, penilaian, observasi, dan refleksi. 
2. Untuk meningkatkan unjuk kerja individual guru dalam rangka pengembangan karir dan promosi jabatan.

3. Untuk mengembangkan pengetahuan profesional dan pemahaman individual guru. Guru disadarkan hakekatnya sebagai praktisi yang reflektif, yang memasuki profesi dengan pengetahuan tertentu, namun memperoleh pengetahuan dan pengalaman baru dibandingkan pengetahuan yang telah dimilikinya.

4. Untuk memberikan kesempatan kepada guru berpartisipasi dan mempersiapkan diri mengalami perubahan. Hal ini dapat diperoleh dengan guru belajar terus menerus dan pengembangan diri dilakukan dalam proses yang panjang. Pengembangan diri dapat diperoleh melalui suatu rangkaian pengalaman yang berkaitan dan bukan pengalaman yang hanya sekali dialami. Akan lebih efektif jika guru didampingi untuk melakukan pengaitan antara pengetahuan yang telah dimiliki dengan pengalaman yang baru diperoleh. Dukungan yang teratur kepada guru dibutuhkan sebagai katalisator penyaluran dari berbagai persoalan yang dihadapi guru selama proses perubahan.

Dengan merujuk kepada keempat alasan yang dikemukakan oleh Luneta (2012), maka analisis kebutuhan pelatihan untuk konteks Indonesia dapat dijelaskan pada uraian berikut ini.

Untuk alasan pertama untuk memperbaiki unjuk kerja guru. Dalam konteks Indonesia unjuk kerja guru diperoleh dari data Penilaian Kinerja Guru (PKG). Dalam Pedoman Pelaksanaan Penilaian Kinerja Guru (PK Guru) tahun 2011 Secara umum, PK GURU memiliki 2 fungsi utama yaitu: untuk menilai kemampuan guru dalam menerapkan semua kompetensi dan keterampilan yang diperlukan pada proses pembelajaran, pembimbingan, atau pelaksanaan tugas tambahan yang relevan dengan fungsi sekolah/madrasah; untuk menghitung angka kredit yang diperoleh guru atas kinerja pembelajaran, pembimbingan, atau pelaksanaan tugas tambahan yang relevan dengan fungsi sekolah/madrasah yang dilakukannya pada tahun tersebut.

Untuk alasan kedua dalam rangka pengembangan karir guru. Secara praktis, karir guru dapat dilihat berdasarkan kepangkatannya. Kepangkatan para guru PNS mengikuti peraturan yang berlaku pada lembaga pemerintah. Sedangkan guru non PNS yang bekerja pada lembaga yang diselenggarakan masyarakat mengikuti aturan yang berlaku pada lembaga yang bersangkutan. Pemerintah secara periodik mengeluarkan data tentang kondisi kepangkatan guru. Tabel mengenai jumlah guru pendidikan dasar per golongan dapat dilihat pada tabel di bawah ini.

REKAPITULASI JUMLAH GURU PER GOLONGAN 2012

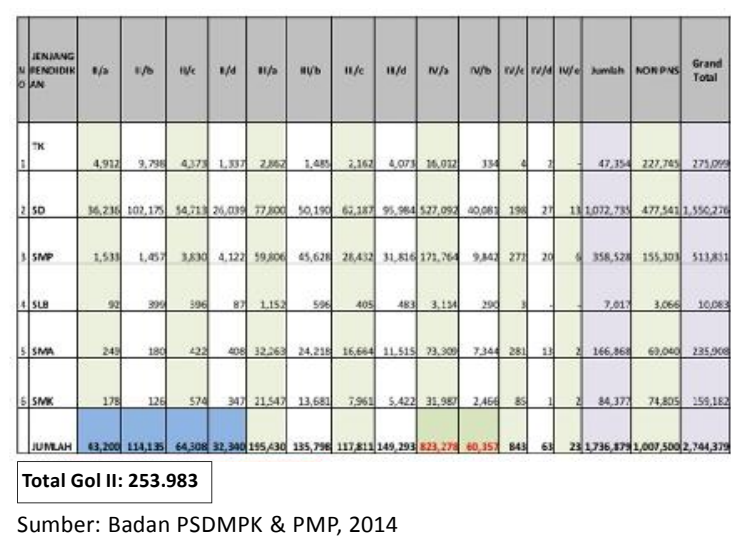

Dari gambar di atas dapat diperoleh data bahwa jumlah terbesar kepangkatan guru berada pada kepangkatan IV/a sebanyak 823.278 orang atau sebesar $29,99 \%$ dari seluruh guru. Dari data di atas juga nampak bahwa terdapat kesenjangan yang antara guru yang berada pada kepangkatan IV/a dengan yang setingkat di atasnya yaitu kepangkatan IV/b. Guru yang berada pada kepangkatan 
IV/b hanya sebesar 7,33 \% jika dibandingkan dengan guru dengan kepangkatan IV/a.

Untuk alasan ketiga pengembangan pengetahuan profesional dan pemahaman individual guru. Dalam konteks Indonesia, penilaian pengetahuan guru dapat diperoleh dari data Uji Kompetensi Guru. Mendikbud merilis bahwa nilai rata-rata uji kompetensi yang dilaksanakan pada tahun 2012 hanya mencapai 42,25 dengan nilai tertinggi 97,0 dan terendah 1,0 (Akuntono,2012). Hasil ini menunjukkan bahwa pengetahuan profesional para guru di Indonesia masih membutuhkan untuk ditingkatkan.

Untuk alasan keempat pemberian kesempatan guru berpartisipasi dan mempersiapkan diri mengalami perubahan. Pendidikan di Indonesia menunjukkan perkembangan yang sangat dinamis. Dinamisasi yang barubaru ini terjadi dan cukup menimbulkan gejolak adalah adanya perubahan kurikulum. Terdapat beberapa resistensi terhadap perubahan kurikulum. Belum lagi beberapa perubahan kebijakan yang berkaitan dengan guru. Tidak semua guru memiliki kesiapan untuk menghadapi perubahan itu.

\section{PERANCANGAN PELATIHAN BERBASIS PEMBELAJAR}

Craft (2000) mengidentifikasi beberapa kelemahan yang biasanya terdapat pada pelatihan dalam rangka pengembangan keprofesian yang disajikan berupa kursus. Kelemahan yang dimaksudkan adalah: didominasi oleh pelatihan di dalam ruangan, disesuaikan dengan keinginan individu daripada kepentingan kelompok guru, tidak dikaitkan dengan kebutuhan sekolah atau departemen, dijalankan berbasis kesukarelaan dan kesukaan terhadap topik pelatihan bukan berdasarkan kebutuhan terbesar, kepesertaan dan materi pelatihan dipilih secara acak sesuai keinginan masing-masing sekolah, memiliki dampak yang terbatas terhadap praktek di sekolah dengan sedikit diseminasi atau tindak lanjut, pelatihan sering dilakukan selama hari efektif belajar sehingga mengganggu proses belajar mengajar, terbuka kemungkinan terjadi konflik antara guru (praktisi) sebagai peserta pelatihan dengan pelatih (ahli teori) yang menyajikan pelatihan, peserta berada pada titik mulai yang berbeda, sehingga pelatihan tidak dapat memuaskan bagi setiap peserta.

Sachs (2007) mengidentifikasi dua jalur pengembangan keprofesian berkelanjutan. Jalur pertama adalah jalur pendekatan pelatihan tradisional dan yang kedua adalah orientasi pembelajaran guru. Pendekatan pelatihan tradisional dilaksanakan dengan pendekatan pembekalan ulang dan pemodelan ulang para guru. Sedangkan orientasi pembelajaran guru menyajikan pendekatan revitalisasi dan reimagining. Setiap pendekatan memiliki karakteristik yang berbeda. Seperti yang diidentifikasi oleh Sachs (2007), guru-guru yang dibutuhkan pada abad 21 adalah guru yang memiliki kemampuan selain praktisi yang terampil juga sebagai pembelajar yang mandiri. Pelatihan yang memberikan peluang lebih besar bagi guru untuk menjadi praktisi dan pembelajar mandiri, menurut Sachs (2007) adalah pelatihan dengan pendekatan re-imagining. Beberapa karakteristik dari pendekatan ini adalah digerakkan oleh hasrat penemuan kembali profesionalitas; bertujuan guru yang transformatif; prosesnya diarahkan untuk membentuk pengetahuan baru dan disepakati antara peserta dan fasilitator; pendekatan yang digunakan adalah inkuiri sebagai praktisi, penelitian tindakan, dan inkuiri sebagai suatu sikap mental, luarannya adalah pengetahuan baru, khayalan yang dibayangkan adalah sebagai agen perubahan. 


\section{PENYAJIAN PELATIHAN YANG MENJAMIN PEMBELAJARAN}

Agar pelatihan tidak hanya sekedar menjadi pertemuan atau lokakarya yang berkaitan dengan pekerjaan, namun menjadi suatu pengembangan keprofesian, maka penyelenggara harus menyadari bahwa kegiatan ini adalah program keprofesian guru (Moeini, 2008). Tanpa hal ini, maka seperti pelatihan-pelatihan yang pernah dilakukan dahulu, pelatihan tidak dapat memenuhi harapan munculnya inisiatif-inisiatif baru pendidikan di sekolah. Pelatihan dalam peningkatan kualitas guru perlu mempertimbangkan beberapa rekomendasi yang telah disusun dalam Konferensi Pendidikan di Indonesia: Mengatasi Krisis Menuju Pembaruan (Jalal dan Supriadi, 2001). Beberapa rekomendasi yang dihasilkan dalam konferensi tersebut dapat disajikan di bawah ini.

Pertama, pendidikan dalam-jabatan ditekankan pada usaha meningkatkan efektivitas mengajarnya, mengatasi persoalanpersoalan praktis dalam pengelolaan kegiatan belajar-mengajar/proses belajar-mengajar, dan meningkatkan kepekaan guru terhadap perbedaan individual para siswa yang dihadapinya. Kegiatan pelatihan harus terkoordinasi antara program-program melalui pemetaan kembali jenis-jenis penataran dengan tujuan untuk meningkatkan efektivitas dan efisiensinya; pembinaan dan pengembangan kemampuan professional guru melalui wadah KKG dan MGMP/BK. Program-program pembinaan mutu guru, baik melalui penataran-penataran maupun pendidikan dalam-jabatan lainnya harus memberikan perhatian penuh terhadap persoalan ini dengan memberikan porsi yang cukup pada "pemahaman tentang dunia anak/ peserta didik".

Kedua, melatih kepekaan guru terhadap latar belakang peserta didik yang semakin beragam. Peserta didik berbeda latar belakangnya, motivasinya, aspirasi pendidikannya, kebutuhan belajarnya, kemampuan dan kecepatan belajarnya, bahkan kondisi fisik dan kesehatannya perlu mendapatkan perhatian yang sewajarnya dari sekolah sesuai dengan keadaannya. Faktor ini ikut menentukan sejauh mana anak merasa termotivasi untuk belajar. Di pihak lain, sebagian kegagalan belajar siswa yang ditun-jukkan oleh keengganan untuk tetap berada di sekolah bersumber dari kurang responsifnya sekolah dan aparat pendidikan terhadap kondisi-kondisi di atas (Lynch, dalam Jalal dan Supriadi, 2001). Kepekaan terhadap keragaman latar belakang siswa dan kemampuan-kemampuan guru untuk menanganinya harus semakin ditampilkan dalam kurikulum pendidikan dalam-jabatan dan pelatihanpelatihan. Paling tidak, antara 20-30\% kurikulum pelatihan guru harus bermuatan topiktopik yang berkenan dengan anak dan latar belakangnya serta implikasinya pada proses belajar-mengajar yang dikelola oleh guru.

Ketiga, lembaga-lembaga diklat dioptimalkan peranannya; kerjasama dengan LPTK ditingkatkan dalam pemanfaatan tenaga, pengembangan kurikulum dan perangkat lunak pelatihan, serta pengembangan sistem akreditasi pelatihan. Untuk meningkatkan peran lembaga diklat, perlu dilakukan usaha-usaha memanfaatkan secara maksimal fasilitas dan peralatan, peningkatan mutu instruktur, pemanfaatan secara maksimal tenaga instruktur yang tersedia di lembaga diklat dengan prinsip pemanfaatan bersama, memanfaatkan potensi lingkungan terutama tenaga yang tersedia di lembaga lain sebagai mitra kerja sama, dalam hal ini LPTK, program-program Diklat dikembangkan dengan berorientasi pada dampak, dikembangkan mekanisme tindak-lanjut guna mengetahui relevansi dan dampak dari diklat, melan- 
jutkan usaha-usaha untuk memetakan kembali jenis-jenis penataran yang diselenggarakan, dan lembaga diklat diciptakan sebagian komunitas belajar bagi para instruktur dan peserta diklat.

Keempat, sekolah diberi kewenangan yang lebih besar untuk menentukan apa yang terbaik untuk pembinaan mutu guru-gurunya, kegiatan penataran dan peningkatan mutu apa yang mereka butuhkan, dimana hal itu akan diperoleh, dengan cara bagaimana dilakukan, berupa biaya dan darimana sumbernya. Salah satu pelajaran dari reformasi pendidikan ialah bahwa reformasi apapun dalam pendidikan hanya berarti apabila terdesiminasi dan berdampak pada tingkat sekolah.

\section{EVALUASI PELATIHAN}

Evaluasi pelatihan suatu tahap yang harus dilakukan, sebagai suatu bagian dari pelatihan yang utuh. Menurut Kirkpatrick (dalam Brown dan Seidner (ed), 1998) ada tiga alasan evaluasi harus dilakukan dalam suatu pelatihan. Alasan pertama adalah para pelatih harus menunjukkan keberadaan sebagai pelatih. Evaluasi yang baik akan semakin memperkuat keberadaannya sebagai pelatih. Alasan kedua adalah evaluasi pelatihan dapat menjadi pertimbangan keberlanjutan pelatihan. Hasil evaluasi pelatihan yang menunjukkan bahwa pelatihan berhasil akan memberikan pertimbangan bahwa pelatihan layak dilanjutkan. Alasan ketiga adalah bahwa melalui evaluasi pelatihan, efektivitas pelatihan dapat diketahui. Pelatihan yang efektif adalah pelatihan yang memberikan dampak bagi peserta pelatihan. Dalam konteks pengembangan keprofesian guru, pelatihan yang baik adalah pelatihan yang memberi dampak bukan hanya bagi guru, namun khususnya bagi peserta didik.

Hasil pelatihan dapat sesuai ataupun tidak sesuai yang direncanakan. Penelitian yang dilakukan oleh Indarti dan Rispantyo (2009) menunjukkan bahwa pendidikan pelatihan memiliki pengaruh yang positif dan signifikan terhadap kinerja guru. Penelitian yang dilakukan oleh Mirza dan Ali (2014) menunjukkan bahwa pelatihan efektif untuk membentuk sikap guru. Pelatihan dapat juga memberikan hasil yang tidak seperti diharapkan atau tidak efektif. Penelitian yang dilakukan oleh Rahmadhani dan Astuti (2009) menunjukkan bahwa pelatihan tidak efektif untuk meningkatkan peran guru, karena dianggap tidak memiliki peran penting dalam memberikan bimbingan kepada siswa. Demikian juga dengan hasil penelitian Sugiyono dan Rahadhini (2011) yang menunjukkan bahwa pendidikan dan pelatihan tidak berpengaruh terhadap kinerja guru.

Suatu pelatihan merupakan suatu proses yang kompleks dan rumit. Berbagai hasil penelitian sebagaimana termuat pada paragraf sebelumnya, walaupun tentu bermanfaat, tidak dapat memberikan gambaran yang utuh tentang efektivitas suatu pelatihan. Brinkerhoff (dalam Brown dan Seidner (ed), 1998) menyatakan bahwa tidak semua komponen dalam pelatihan dapat diberikan bobot yang sama dalam evaluasi pelatihan. Menurut Brinkerhoff (dalam Brown dan Seidner (ed), 1998) terdapat tujuh tipe tujuan pelatihan yang secara urutan alfabet dibuat menjadi peringkat. Type A: Current Job Peiformance: penyajian ketrampilan dan pengetahuan yang dibutuhkan untuk memiliki unjuk kerja yang lebih efektif pada pekerjaan yang sekarang dilakukan; Type B: Advancement \& Promotion: penyajian ketrampilan dan pengetahuan yang dibutuhkan untuk mencapai promosi dan peningkatan karir lainnya; Type C: Organizational Capacity: pembangunan kapasitas organisasi dalam rangka antisipasi masa depan melalui memberikan ketrampilan dan pengetahuan yang mungkin dibutuh- 
kan di masa depan; Type D: Orientation \& Acculturation: penyajian pengetahuan dan pemahaman mengenai profesi yang sedang diampu, budaya organisasi, kebijakan dan hal penting untuk menjadi tenaga profesional; Type E: Employee Capacity : peningkatan kapasitas dalam rangka meningkatkan daya lenting (resiliency) yang dibutuhkan untuk menunjukkan unjuk kerja yang lebih efektif dalam pekerjaan sehari-hari; Type F: Leadership Capacity : pengembangan kepemimpinan dalam organisasi; Type G: Personal Benefits: penyajian kesempatan belajar untuk memperoleh keuntungan yang ingin diperoleh. pembagian tipe-tipe tersebut memberi inspirasi kepada para penyelia pelatihan untuk menitikberatkan evaluasi pada bagian yang penting dan tidak memberikan bobot yang tinggi pada bagian yang kurang penting. Jelas nampak dalam pembagian tipe itu, bahwa keuntungan individu peserta pelatihan merupakan bagian yang paling kurang penting dibandingkan tipe lainnya. Tipe pencapaian pelatihan yang paling penting untuk dievaluasi menurut Brinkerhoff (dalam Brown dan Seidner (ed), 1998) adalah ketrampilan dan pengetahuan yang dibutuhkan untuk menunjukkan unjuk kerja yang efektif pada pekerjaannya sekarang (Type A).

Terdapat beberapa model evaluasi pelatihan, misalnya model empat level yang dikemukakan oleh Kirkpatrick (dalam Brown dan Seidner (ed), 1998) dan model RoI yang dikembangkan oleh Phillips (dalam Brown dan Seidner (ed), 1998) sebagai penyempurnaan dari model empat level Kirkpatrick. Sedangkan secara teknik, teknik observasi ketika digunakan mengevaluasi dampak pelatihan dapat memberikan banyak manfaat, sebagaimana hasil penelitian yang dilakukan Rose dan David (2007).

\section{PEMBAHASAN}

Berdasarkan paparan di atas, pelatihan dalam rangka pengembangan keprofesian berkelanjutan dapat dirancang dengan memperhatikan beberapa hal di bawah ini. Perancangan pelatihan ini dapat menuntun para pengambil kebijakan untuk menentukan model pelatihan yang sesuai dengan kondisi Indonesia dalam rangka pengembangan keprofesian berkelanjutan guru.

Pertama, kebutuhan pelatihan guru dapat diperoleh dari analisis butir-butir uji kompetensi yang dapat menggambarkan kesenjangan kompetensi, kesulitan guru dalam memenuhi angka kredit, dan alasan resistensi guru terhadap perkembangan pendidikan yang dinamis. Analisis butir-butir uji kompetensi, baik kompetensi pedagogik maupun kompetensi profesional, hanya dapat dilakukan jika hasil uji kompetensi diadministrasi dengan baik. Guru tidak hanya mendapatkan nilai akhirnya saja, namun dilengkapi dengan daftar kompetensi yang belum dikuasai. Kesulitan guru dalam memenuhi angka kredit biasanya bersumber dari belum terbiasanya guru menyusun karya tulis ilmiah dan dipublikasikan. Untuk itulah diperlukan pelatihan yang melibatkan pemangku kepentingan yang berkaitan dengan karya tulis ilmiah dan publikasi, misalnya LPTK, LPMP, dan P4TK. Resistensi guru terhadap perkembangan pendidikan yang dinamis muncul dapat diakibatkan dari komunikasi yang kurang baik antara pengambil kebijakan di satu sisi dan guru di sisi yang lain. Misalnya penolakan terhadap pemberlakukan kurikulum 2013 lebih karena tidak semua guru siap dan terlatih dalam pelaksanaan kurikulum. Kajian terhadap alasan penyesuaian kurikulum dan pembelajaran di kelas seringkali tidak terkomunikasikan kepada para praktisi. 
Kedua, pelatihan dirancang dengan pendekatan re-imagining yang mengarahkan guru untuk menjadi agen perubahan. Guru dapat diajak untuk membayangkan dan merumuskan kembali guru yang ideal. Rumusan ini selanjutnya dianalisis kesenjangannya dengan kondisi dan situasi guru saat ini. Tindakan reflektif ini memungkinkan guru untuk menjadi pembelajar yang otomatis dan otonom, sehingga menghasilkan identitas guru yang otentik. Guru akan mampu memberdayakan dirinya sendiri menjadi guru yang profesional, cukup dengan intervensi minimal dari pihak-pihak di luar guru.

Ketiga, penyajian pelatihan yang menjamin pembelajaran harus dirancang untuk meningkatkan efektivitas pengajaran, mengasah kepekaan terhadap peserta didik, melibatkan LPTK dan lembaga diklat, dan memberikan kewenangan kepada sekolah untuk menentukan pelatihan yang dibutuhkan. Pelatihan harus disajikan dengan memberikan porsi yang cukup untuk guru dapat merefleksi yang sudah dilakukan dan mempraktekkan perolehan yang baru. Guru perlu mengasah kepekaan terhadap situasi dan kondisi peserta didik yang sangat beragam seiring dengan kebijakan pendidikan untuk semua. Kepekaan ini penting, agar guru mampu memberikan layanan dan intervensi yang cocok bagi setiap peserta didik, sehingga peserta didik mampu belajar sesuai karakteristiknya. Pelatihan yang melibatkan LPTK sebagai center of excellent harus diusahakan maksimal. Dosen-dosen yang secara khusus mendalami suatu topik dapat berbagi dengan para guru sebagai praktisi. Kiranya kerja sama ini dapat saling menguntungkan dan menghilangkan dikotomi antara teori dan praktek. Pelaksanaan pelatihan harus disesuaikan dengan kebutuhan dan budaya warga sekolah agar pelatihan lebih mendekati kenyataan di sekolah. Pelatihan yang demikian akan memudahkan guru melaksanakan hasil pelatihan dan melakukan pengimbasan kepada guru yang lain. Tentunya luaran pelatihan yang diharapkan adalah hasil pelatihan dapat diterapkan di sekolah dan berdampak kepada peserta didik.

Keempat, evaluasi proses pelatihan harus dititikberatkan pada ketrampilan dan pengetahuan yang dibutuhkan untuk menunjukkan unjuk kerja yang efektif pada pekerjaannya sekarang. Evaluasi pelatihan, baik oleh penyelia, pengguna, maupun penyelenggara pelatihan mutlak diperlukan. Namun titik berat evaluasi perlu diperhatikan. Pelatihan yang berhasil tentunya bukan agar peserta mendapatkan sertifikat semata dan memperoleh angka kredit. Pelatihan yang berhasil, paling mudah dilihat dari apakah setelah mengikuti pelatihan, guru menjadi lebih efektif dalam melakukan pekerjaannya sebagai guru. Teknik observasi dapat digunakan oleh penyelia untuk mengevaluasi dampak dari pelatihan. Melalui observasi, perubahan-perubahan yang terjadi setelah pelatihan dapat dianalisis. Hasil analisis dapat digunakan untuk merencanakan pelatihanpelatihan berikutnya.

\section{SIMPULAN}

Berdasarkan tinjauan teori dan pembahasan, maka dapat disimpulkan bahwa model pelatihan dalam rangka pengembangan keprofesian berkelanjutan yang paling sesuai adalah model School focused: University School Partnerships (Berfokus sekolah: kemitraan sekolah dan perguruan tinggi). 


\section{DAFTAR PUSTAKA}

Akuntono, Indra.2012. Rata -ata Hasil Uji Kompetensi guru Masih Rendah. http:/ /edukasi.kompas.com/ read/2012/03/ 16/ 17455390/Rata.rata. Hasil.Uji. Kompetensi.Guru.Masih.Rendah. Diakses 14 Maret 2014

Badan BPSDMPK \& PMP.2014.Sistem Pembinaan Guru Profesional. Tersedia dalam http://www.slideshare.net/ kie242004/profesi-guru-42111282. Diakses 28 November 2014

Brinkerhoff, Robert O. Clarifying And Directing Impact Evaluation. Dalam Brown, Stephen M. dan Constance J. Seidner.1998. Evaluating Corporate Training:Models and Issues. New York: Springer Science + Business Media

Craft, Anna.2000. Continuing Professional Development: A Practical Guide For Teachers And Schools: Taylor \& Francis e-Library

Furjanic, Sheila W \& Laurie A Trotman. 2000.Turning Training into Learning. New York : AMACOM

Jalal, Fasli dan Dedi Supriadi (ed). 2001. Reformasi Pendidikan Dalam Konteks Otonomi Daerah. Yogyakarta:Adicita Karya Nusa.

Herawan, Endang dan Nani Hartini. Manajemen Tenaga Pendidik dan Kependidikan. Dalam Tim Dosen Administrasi Pendidikan Universitas Pendidikan Indonesia.2014. Manajemen Pendidikan. Bandung:Alfabeta

Indarti, Sri dan Rispantyo.2009.Pengaruh Pendidikan Pelatihan, Motivasi Kerja dan Lingkungan Kerja Terhadap Kinerja Guru Sekolah Dasar. Jurnal Manajemen Sumberdaya Manusia. Volume 3 No. 2 Desember 2009
Kementrian Pendidikan Nasional. 2011. Pedoman Pengelolaan Pengembangan Keprofesian Berkelanjutan. Jakarta: Kementrian Pendidikan Nasional

Kementrian Pendidikan Nasional. 2011. Pedoman Penilaian Kinerja Guru (PK Guru).Jakarta: Kementrian Pendidikan Nasional

Kirkpatrick, Donald L.The Four Level of Evaluation. Dalam Brown, Stephen M. dan Constance J. Seidner (eds).1998. Evaluating Corporate Training: Models and Issues. New York: Springer Science+Business Media

Luneta, K.2012. Designing Continuous Professional Development Programmes For Teachers: A literature review. Tersedia dalam http://web.a.ebscohost. com $/$ ehost $/$ detail $/$ detail ? vid $=11 \&$ sid= 537f9655-4079-4ace-8dc1-872d e 57 ec0e\%40sessionmgr4004 \& hid $=4107 \& b d a t a=J n N p$ dGU9ZWhvc3QtbGl2ZQ\%3d \% 3d\# $\mathrm{AN}=82611189 \& \mathrm{db}=\mathrm{ehh}$. Diunduh tanggal 15 Juni 2014

McKinsey \& Company.2007. How the World's Best- Performing School Systems Come Out on Top. Laporan penelitian. Tersedia dalam http:// mckinseyonsociety.com/downloads/ reports/Education/Worlds_ School_ Systems_Final.pdf. Diunduh 27 November 2014

Mirza, Munawar S., Asghar Ali. 2014. Effectiveness of Training Program in Changing Teachers' Attitude towards Students' Corporal Punishment. Journal of Research and Reflections in Education Vol.8, No.2, pp 97-104. Tersedia dalam http://www.ue.edu.pk/jrre

Moeini, Hosein. 2008. Identifying Needs: A Missing Part in Teacher Training Programs. Tersedia dalam www. 
seminar.net/images/stories/vol4issue $1 /$ moini-identifyingneeds.pdf. Diunduh tanggal 14 Juni 2014.

Phillips, Jack J. Level Four and Beyond : An ROI Model. Dalam Brown, Stephen M. dan Constance J. Seidner (eds).1998. Evaluating Corporate Training: Models and Issues. New York: Springer Science+ Business Media.

Rahmadhani A, Azisah dan Yulianti Dwi Astuti.2009. Efektivitas Pelatihan Peningkatan Peran Guru dalam Memberi-kan Bimbingan Kepada Siswa. Tersedia dalam http:// psychology.uii.ac.id/images/stories/ jadwal kuliah/naskah-publikasi01320336.pdf. Diunduh tangga 13 Juni 2014.
Rose, Jo \& David Reynolds.2007.Teachers' Continuing Professional Development: A New Approach. tersedia dalam http:/ /www.fm-kp.si/zalozba/ISBN/978961-6573-65-8/219-240.pdf. Diunduh tanggal 10 Juli 2014

Sachs, Judyth. 2007. Learning to Improve or Improving Learning: The Dilemma of Teacher Continuing Professional Development. Tersedia dalam www.fm-kp.si/zalozba/ISBN/978-9616573-65-8/009-020.pdf. Diunduh tanggal 10 September 2014.

Sugiyono dan MD Rahadhini.2011.Pengaruh Pendidikan Pelatihan, Motivasi Kerja, dan Lingkungan Kerja Terhadap Kinerja Guru. Jurnal Manajemen Sumber Daya Manusia. Volume 5 No. 1 Juni 2011. 